\title{
Awareness regarding healthcare services of Janani Shishu Suraksha Karyakaram among beneficiaries in Kamla Nehru hospital, Shimla, HP
}

\author{
Mridul Acharya ${ }^{1}$, Suchpreet Kaur ${ }^{2}$, Dr. NL Gupta ${ }^{3}$, Dr. Neelam Kaur ${ }^{4}$ \\ ${ }^{1} \mathrm{MPH}$ Scholar, \\ ${ }^{2}$ Assistant Professor, Department of Public Health, \\ ${ }^{3}$ Associate Professor, Department of Public Health \\ ${ }^{4}$ Dean Faculty of Health and Allied Sciences, Eternal University, Baru Sahib, HP, India
}

\begin{abstract}
Introduction: The JSSK was launched in 2011 with the major objective to eliminate out-of-pocket expenditure and entitle all the pregnant women (BPL/APL, urban/rural) with free health services in any government health facilities.
\end{abstract}

Materials and Methods: A cross sectional study was carried out on 356 pregnant beneficiaries chosen by proportionate sampling from the department of Obstetrics, State Kamla Nehru Hospital, Shimla. Face to face interview was held with pretested structured questionnaire to elicit information and the data was analyzed by standard statistical measures.

Results: Majority $(72.5 \%)$ of the women had moderately adequateawareness, whereas $16.3 \%$ beneficiaries had adequate and $11.2 \%$ beneficiaries had inadequate awareness regarding the healthcare services of the JSSK.The study revealed that awareness was highly significantly associated with place of residence $(p=0.001)$, Education $(p=0.002)$, occupation $(p=0.001)$ and parity $(p=0.001)$. Conclusion: Awareness level of JSSK entitlements in the beneficiaries in our study was moderately adequate. Maximum awareness was noticed for the provision of free vaginal delivery whereas awareness for provisions like free caesarean section, free drop back facility to home, free provision of blood was very low.

Key words: JSSK, Awareness, Beneficiaries

\section{Introduction}

Providentially, the maternal health has been at the forefront of global and national health policies for the last few years. Under Rural Health Mission, 2005, the Janani Suraksha Yojana (JSY) was implemented all over India. However, the JSY was not able to adequately achieve its goals, as mere cash incentives were not enough to attract people to public institutions. On the contrary, the scheme encouraged corruption, while beneficiaries continued to spend on services such as diet, diagnostics, transport, etc. Consequently Govt. replaced it by Janani Shishu Suraksha Karyakaram (JSSK) in 2011. The major objective of the scheme was to eliminate out-of-pocket expenditure and entitle all the pregnant women (BPL/APL, urban/rural) free treatment, drug, diagnostics, diet, blood transfusion and transport services for antenatal care, institutional delivery, and post-natal and neonatal care newborn babies up to 30 days in any government health facilities.(Ministry of Health and Family Welfare, 2011). Direct cost incurred by the end user was considered as out-of-pocket (OOP) expenditure and both the terms were used interchangeably (Lyengar SD 2009).

Globally, the infant mortality rate had decreased from an estimated rate of 65 deaths per 1000 live births in 1990 to 29 deaths per 1000 live births in 2017 and Annual infant deaths from 8.8 million in 1990 to 4.1 million in 2017 (WHO 2017).

India has registered a significant decline of 8\% in Infant mortality Rate (IMR) in 2016 (SRS, 2016). IMR in India has declined by three points from 37 per 1000 live births in 2015 to 34 per 1000 live births in 2016 and it has declined to 32 per 1000 live births in 2017 (World bank). The IMR in Himachal Pradesh 25 per 1000 live births (Govt. of H.P. 2017). However, maternal health care is still a challenge to global public health system, especially in developing countries like India (Angedi et al, 2016). The maternal mortality ratio (MMR) in India has declined from 167 in 2011-2013 to 130 per 1,00,000 live births in 2014-2016 and highest rate of MMR was in Assam 237 per 1, 00,000 live births. (World bank).Institutional deliveries in the Himachal Pradesh increased from 63.4\% in 2010- 
11 to $75.5 \%$ in 2012-2013 after implementing JSSK (TYAGI et al, 2016).

The utilization of any scheme including JSSK depends on the level of awareness of the pregnant or postnatal women. Despite of wide availability of the JSSK scheme, its entitlements, free treatment, drug, diagnostics, diet, blood transfusion and transport services have been poorly utilized. It may be due to ignorance or due to incomplete/ faulty information about their use and procurement. Awareness level among beneficiaries helps us to know the extent to which the programme is serving the purpose at root level. (Sonali 2016)For effective utilization of these schemes, awareness of the same is needed among women. Non-utilization or under-utilization of maternal health care services/benefits of the schemes especially amongst the poor and slum population is due to lack of awareness or access to health care services and failure of Government to communicate them is a major factor. (Manjula $\mathrm{K}$ 2016 )

\section{Materials and Methods:}

A cross sectional study was conducted in the Kamla NehruHospital, Shimla Himachal Pradesh, India. It is the capital of Himachal Pradesh.

\section{Inclusion Criteria-}

- Beneficiaries who availed the benefits of JSSK.

- Those beneficiaries who were attending OPD and admitted in IPD ward in KNH, Shimla.

\section{Exclusion Criteria-}

- Women who were not availing JSSK.

- Those beneficiaries who were not willing to participate in the study.

Sample size calculation was done using the following formula:

$$
n=\frac{N Z^{2} p(1-p)}{d^{2}(N-1)+Z^{2} p(1-p)}
$$

Where, $\mathrm{n}=$ sample size

$$
\begin{aligned}
& \mathrm{N}=\text { Population }=2859 \\
& \mathrm{~d}=\text { degree of accuracy }=5 \%=0.05
\end{aligned}
$$

$\mathrm{P}=$ Expected prevalence $=0.5$

$\mathrm{Z}=$ Standard normal variate statistic at $95 \%$ level of confidence $=1.96$

Hence, sample size $=339$

Considering the non-response rate of (5\%), thus the final sample size was 356.

Sampling technique adopted proportionate technique and purposive technique was carried out to obtain the required sample size from the population, and the list of IPD and OPD of Obstetrics were taken from KNH hospital.

\section{Data collection tool and technique}

Data was collected by structured questionnaire tool and face to face technique was used. The structured interview scheduled with open and closed-ended questions were framed taking extensive reference to research paper and literature. The questions were made in simple language. The questionnaire consisted of 2 sections, section A and B. Section A included 9 questions to elicit information regarding socio demographic variables of the sample and section B included 16 questions to elicit information regarding awareness of JSSK among beneficiaries while incorporating few NRHM questions. 


\section{SAMPLING TECHNIQUE}

Figure: 1

TOTAL REGISTRATION IN OPD \& IPD IS 2859 OF KNH
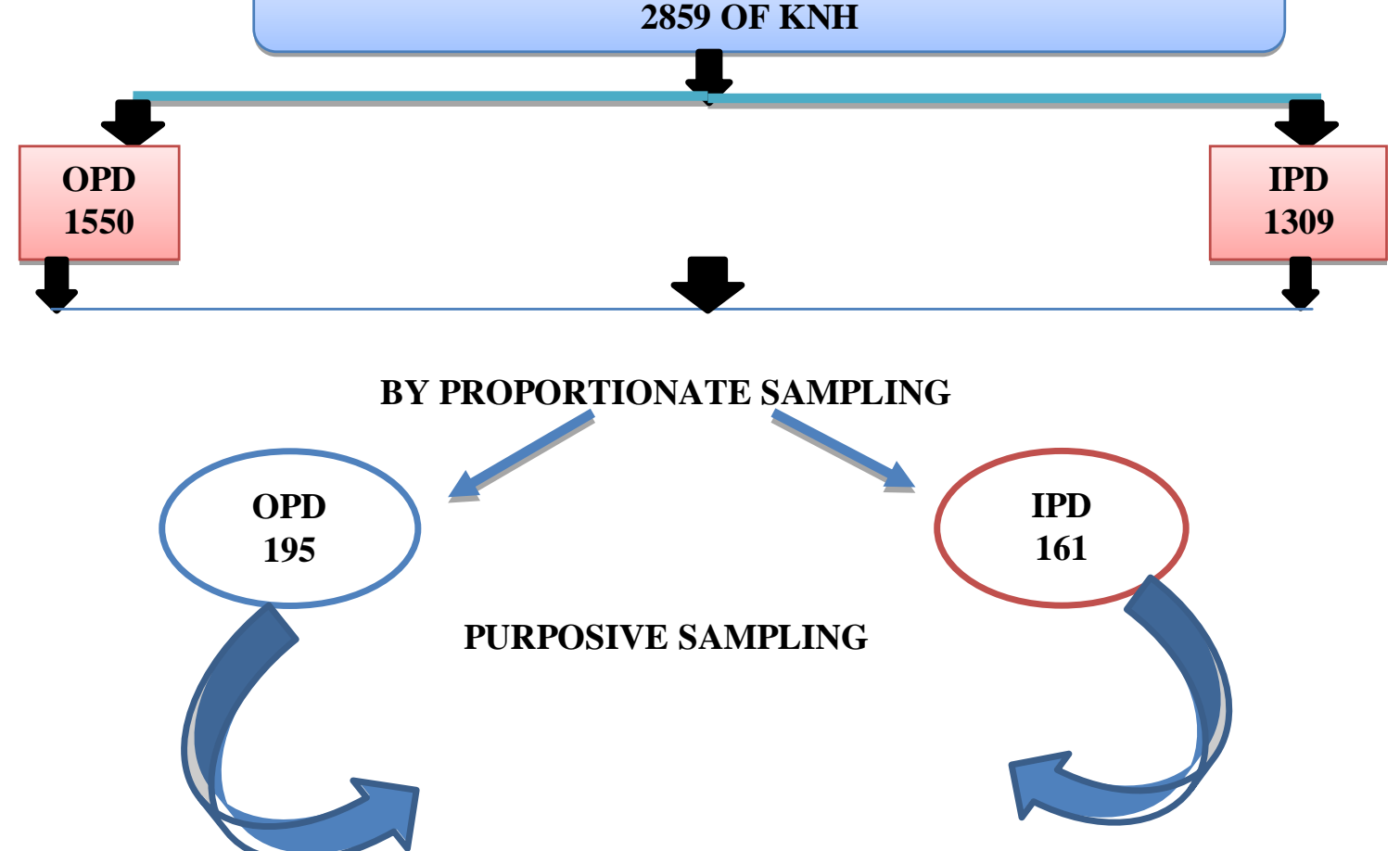

Criterion Measurement for the assessment of level of awareness is as follows:Table: 1

\begin{tabular}{|l|l|l|}
\hline Category & Score level & Score \\
\hline Adequate & $>75 \%$ & $>12$ \\
\hline Moderately adequate & $25-75 \%$ & $4-12$ \\
\hline Inadequate & $<25$ & $<4$ \\
\hline
\end{tabular}

Level of awareness was assessed by taking reference of taking methods and classified as: adequate awareness for those respondents who secured above $75 \%$, moderately adequate for those who secured between $25-75 \%$ and Inadequate level for those who secured less than $25 \%$.

During this period, all the beneficiaries of JSSK attending and admitted in KNH, who were selected, were interviewed at the hospital. Each of these respondents was provided the details of objectives of the study. All interviews were preceded by an informed consent. The consent form was read out to them and was explained to them. Respondent gave consent, interviews were conducted.

\section{Data Processing and Analysis}

Data entry and processing and analysis were done in statistical package for social sciences (SPSS version 23). Descriptive statistics such as mean, S.D, frequency distribution and cross tabulation between dependent and independent variables were applied to describe and summarize the basic background and characteristics of the respondents. Inferential statistics chi square test was used to show association between dependent and independent variable. 


\section{RESULTS}

Table 2: Socio Demographic Characteristics of Beneficiaries

\begin{tabular}{|c|c|c|}
\hline Category & Frequency $(\mathbf{n})$ & Percentage $(\%)$ \\
\hline \multicolumn{3}{|l|}{ Age Group } \\
\hline $18-28$ years & 226 & 63.5 \\
\hline 29-38 years & 129 & 36.2 \\
\hline $39-48$ years & 1 & .3 \\
\hline \multicolumn{3}{|c|}{ Mean $=26.8 \pm 19.2$} \\
\hline \multicolumn{3}{|l|}{ Place of residence } \\
\hline Urban & 64 & 18.0 \\
\hline Rural & 205 & $\mathbf{5 7 . 6}$ \\
\hline Tribal & 87 & 24.4 \\
\hline \multicolumn{3}{|l|}{ Marital Status } \\
\hline Married & 345 & 96.9 \\
\hline Widow & 11 & 3.1 \\
\hline \multicolumn{3}{|l|}{ Education } \\
\hline Illiterate & 12 & 3.4 \\
\hline Primary school certificate & 51 & 14.3 \\
\hline Middle school certificate & 102 & 28.7 \\
\hline High school certificate & 139 & 39.0 \\
\hline Graduate & 31 & 8.7 \\
\hline Profession or Honors & 21 & 5.9 \\
\hline \multicolumn{3}{|l|}{ Occupation } \\
\hline $\begin{array}{l}\text { Unemployed/ } \\
\text { Homemaker }\end{array}$ & 188 & 52.8 \\
\hline Service/ employee & 22 & 6.2 \\
\hline Agricultural & 91 & 25.6 \\
\hline Own business & 55 & 15.4 \\
\hline \multicolumn{3}{|l|}{ Husband Occupation } \\
\hline Government job & 26 & 7.3 \\
\hline Agricultural & 173 & 48.6 \\
\hline Laborer & 28 & 7.9 \\
\hline
\end{tabular}




\begin{tabular}{|c|c|c|}
\hline Own business & 129 & 36.2 \\
\hline \multicolumn{3}{|l|}{ Type of family } \\
\hline Single & 64 & 18.0 \\
\hline Nuclear & 20 & 5.6 \\
\hline Joint & 272 & 76.4 \\
\hline \multicolumn{3}{|l|}{ Family Income } \\
\hline Less than 6,323 & 62 & 17.4 \\
\hline $6327-18,949$ & 264 & 74.2 \\
\hline $18,953-31589$ & 20 & 5.6 \\
\hline $31,591-47262$ & 2 & .6 \\
\hline $47,266-63178$ & 8 & 2.2 \\
\hline \multicolumn{3}{|l|}{ Parity } \\
\hline Single & 168 & 47.2 \\
\hline Two/ or More Children & 188 & 52.8 \\
\hline
\end{tabular}

Above table reveals that the socio demographic characteristics of the respondents. The maximum number $(63.5 \%)$ of beneficiaries was in the age group of $19-28$ years. The mean age and SD of the respondents was $26.8 \pm 19.2$ years. The minimum age was 18 years and the maximum age was 48 years. Most (57.6\%) of the respondents were from rural area. Majority (96.9\%) were married. Most of them $(39.0 \%)$ were educated up to high school certificate. Similarly, majority $(28.7 \%)$ were educated up to middle school certificate. More than half (52.8\%) women were homemakers. $48.6 \%$ women's husband were agriculturalist. Majority, (76.4\%) belonged to joint family. Regarding family's income more than half of the respondents (74.2\%) were having 6327-18,949. Majority $(52.8 \%)$ had two or more children.

\section{Awareness regarding JSSK}

Table 3: Frequency and percentage distribution of beneficiaries according to the level of awareness regarding JSSK

\begin{tabular}{|c|c|c|c|c|}
\hline Category & Score level & Score & Frequency & Percentage \\
\hline Adequate & $>75 \%$ & $>12$ & 58 & $16.3 \%$ \\
\hline Moderately adequate & $25-75 \%$ & $4-12$ & 258 & $72.5 \%$ \\
\hline Inadequate & $<25$ & $<4$ & 40 & $11.2 \%$ \\
\hline
\end{tabular}

Table depicts the frequency and percentage distribution of the awareness level regarding the healthcare services JSSK scheme according to the criterion measure and it revealed that majority $72.5 \%$ of the beneficiaries had moderately adequate awareness whereas $16.3 \%$ beneficiaries had adequate and $11.2 \%$ beneficiaries had inadequate awareness regarding the healthcare services of the JSSK. 


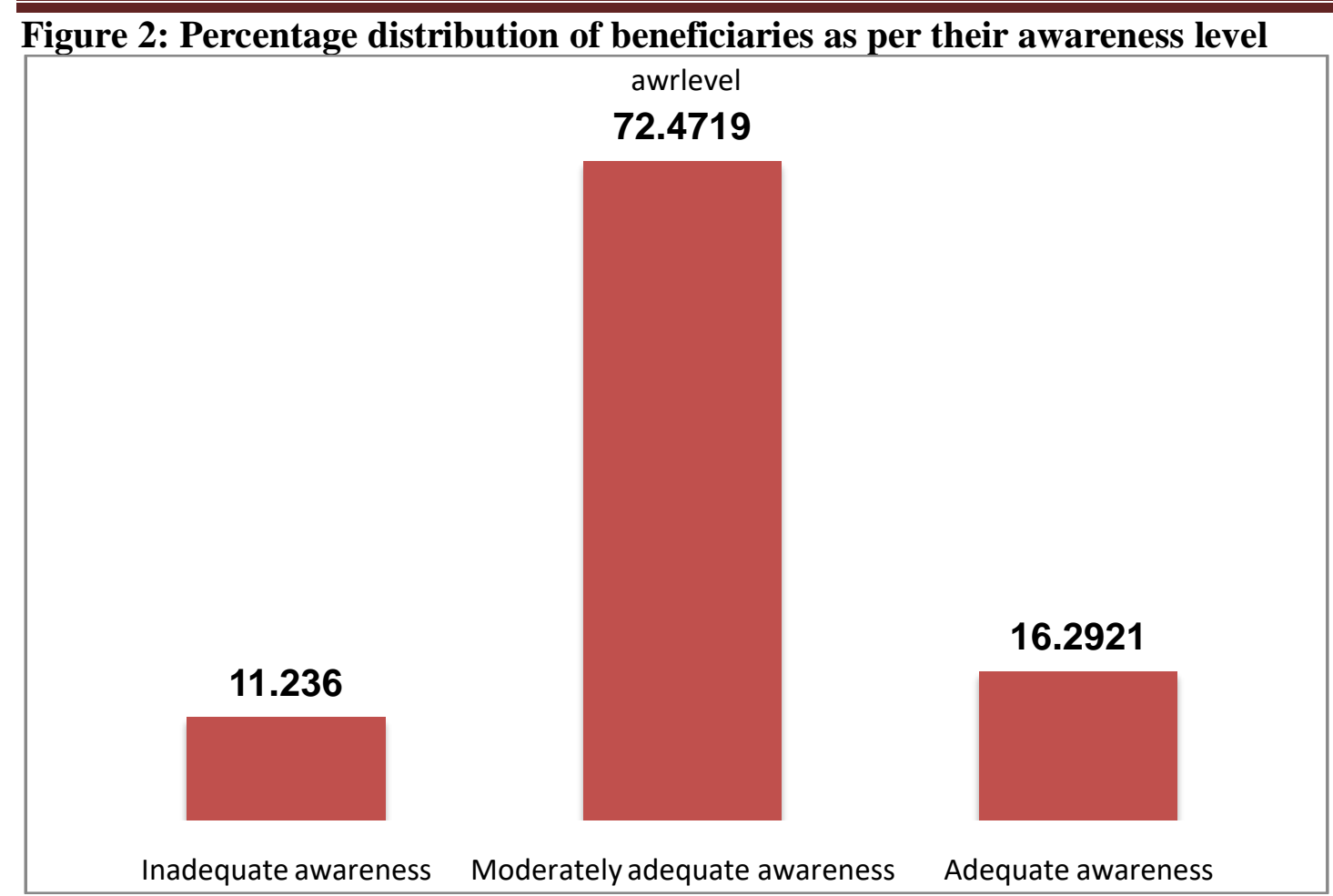

Figure 2: indicates that majority $72.5 \%$ had moderately awareness of JSSK.

Table 4 Awareness regarding JSSK among beneficiaries

\begin{tabular}{|c|c|c|c|}
\hline & Category & Frequency & Percentage \\
\hline \multicolumn{4}{|c|}{ Awareness about the entitlements for mothers } \\
\hline \multirow{2}{*}{$\begin{array}{l}\text { 1.Heard the name of } \\
\text { JSSK }\end{array}$} & Yes & 67 & 18.8 \\
\hline & No & 289 & 81.2 \\
\hline \multirow{2}{*}{$\begin{array}{l}\text { 2.Free and zero expenses } \\
\text { delivery and caesarean } \\
\text { section }\end{array}$} & Yes & 330 & 92.7 \\
\hline & No & 26 & 7.3 \\
\hline \multirow{2}{*}{$\begin{array}{l}\text { 3.Free drugs and } \\
\text { consumables }\end{array}$} & Yes & 300 & 84.3 \\
\hline & No & 56 & 15.7 \\
\hline \multirow{2}{*}{$\begin{array}{l}\text { 4.Free essential } \\
\text { diagnostic tests }\end{array}$} & Yes & 286 & 80.3 \\
\hline & No & 70 & 19.7 \\
\hline \multirow{2}{*}{$\begin{array}{l}\text { 5.Free provision of } \\
\text { blood }\end{array}$} & Yes & 46 & 12.9 \\
\hline & No & 310 & 87.1 \\
\hline \multirow{2}{*}{$\begin{array}{l}\text { 6.Free diet during stay in } \\
\text { the health institution }\end{array}$} & Yes & 172 & 48.3 \\
\hline & No & 184 & 51.7 \\
\hline \multirow[t]{2}{*}{ 7. Free transport } & Yes & 164 & 46.1 \\
\hline & No & 192 & 53.9 \\
\hline
\end{tabular}




\begin{tabular}{|c|c|c|c|}
\hline \multirow{2}{*}{$\begin{array}{l}\text { 8. Free transport btw the } \\
\text { facilities }\end{array}$} & Yes & 262 & 73.6 \\
\hline & No & 94 & 26.4 \\
\hline \multirow{2}{*}{$\begin{array}{l}\text { 9. Drop back from } \\
\text { hospital to home }\end{array}$} & Yes & 187 & $\mathbf{5 2 . 5}$ \\
\hline & No & 169 & 47.5 \\
\hline \multicolumn{4}{|c|}{ Awareness about entitlements for sick infants } \\
\hline \multirow{2}{*}{$\begin{array}{l}\text { 10. Free treatment of } \\
\text { sick infants }\end{array}$} & Yes & 260 & 73.0 \\
\hline & No & 96 & 27.0 \\
\hline \multirow{2}{*}{$\begin{array}{l}\text { 11. Free drugs and } \\
\text { consumables for infants }\end{array}$} & Yes & 280 & 78.7 \\
\hline & No & 76 & 21.3 \\
\hline \multirow{2}{*}{$\begin{array}{l}\text { 12. Free diagnostics for } \\
\text { sick infants }\end{array}$} & Yes & 169 & 47.5 \\
\hline & No & 187 & $\mathbf{5 2 . 5}$ \\
\hline \multirow{2}{*}{$\begin{array}{l}\text { 13. Free provision of } \\
\text { blood }\end{array}$} & Yes & 79 & 22.2 \\
\hline & No & 277 & $\mathbf{7 7 . 8}$ \\
\hline \multirow{2}{*}{$\begin{array}{l}\text { 14. Free transport for } \\
\text { sick infants from home } \\
\text { to hospital }\end{array}$} & Yes & 264 & 74.2 \\
\hline & No & 91 & 25.6 \\
\hline \multirow{2}{*}{$\begin{array}{l}\text { 15. From institute to } \\
\text { institute }\end{array}$} & Yes & 213 & 59.8 \\
\hline & No & 143 & 40.2 \\
\hline \multirow{2}{*}{$\begin{array}{l}\text { 16. Free transport from } \\
\text { health to home }\end{array}$} & Yes & 175 & 49.2 \\
\hline & No & 181 & 50.8 \\
\hline
\end{tabular}

Table 4 indicates that awareness level of women. Out of 356 beneficiaries, only $18.8 \%$ women heard about the JSSK. Majority (92.7\%) were aware about free and zero expanses delivery and caesarean section, followed by $84.3 \%, 80.3 \%$ free drugs and consumables and free essential diagnostic tests. Least awareness $(47.5 \%)$ respondents were aware about free diagnostic tests, and $(22.2 \%)$ respondents were aware regarding free provision of blood for sick infants.

Table 5: Association of Socio- demographic variables with the Awareness Level:-

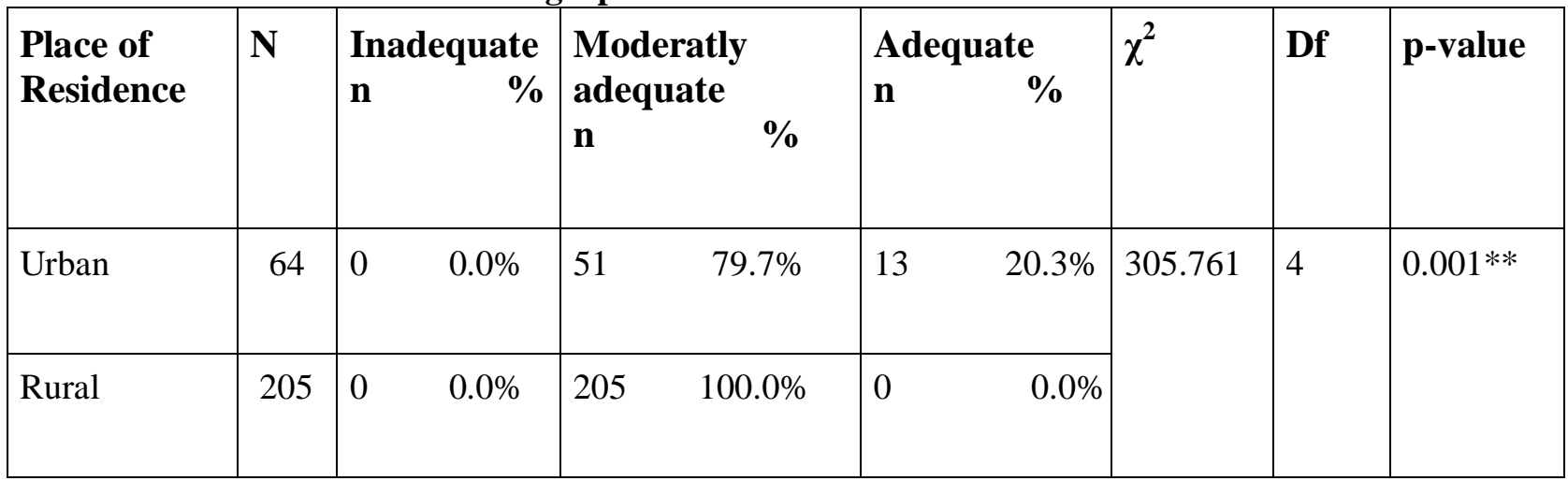


DOI : https://dx.doi.org/10.26808/rs.ph.i10v1.02

International Journal of Pharmaceutical Science and Health Care

Issue 10, Vol.1 (Jan. Feb 2020)

Available online on http://www.rspublication.com/ijphc/index.html

ISSN $2249-5738$

\begin{tabular}{|c|c|c|c|c|c|c|c|c|c|c|}
\hline Tribal & 87 & 40 & $46.0 \%$ & 2 & $2.3 \%$ & 45 & 51.7 & & & \\
\hline Education & $\mathbf{N}$ & $\begin{array}{l}\text { In: } \\
\text { n }\end{array}$ & $\begin{array}{r}\text { lequate } \\
\%\end{array}$ & $\begin{array}{l}\text { Moc } \\
\text { adec } \\
\mathbf{n}\end{array}$ & $\begin{array}{l}\text { atly } \\
\text { ite }\end{array}$ & $\begin{array}{l}\text { Ad } \\
\text { n }\end{array}$ & $\begin{array}{l}\text { uate } \\
\qquad \%\end{array}$ & $\chi^{2}$ & Df & p-value \\
\hline Illiterate & 12 & 0 & $0.0 \%$ & 12 & $100.0 \%$ & 0 & $0.0 \%$ & 34.411 & 10 & $0.002 *$ \\
\hline $\begin{array}{l}\text { Primary } \\
\text { school } \\
\text { certificate }\end{array}$ & 51 & 1 & $2.0 \%$ & 5 & $9.8 \%$ & 45 & $88.2 \%$ & & & \\
\hline $\begin{array}{l}\text { Middle } \\
\text { school } \\
\text { certificate }\end{array}$ & 102 & 38 & $37.3 \%$ & 59 & $57.8 \%$ & 5 & $4.9 \%$ & & & \\
\hline $\begin{array}{l}\text { High school } \\
\text { certificate }\end{array}$ & 139 & 1 & $0.7 \%$ & 138 & $99.3 \%$ & 0 & $0.0 \%$ & & & \\
\hline Graduate & 31 & 0 & $0.0 \%$ & 31 & $100.0 \%$ & 0 & $0.0 \%$ & & & \\
\hline $\begin{array}{l}\text { Profession or } \\
\text { Honors }\end{array}$ & 21 & 0 & $0.0 \%$ & 13 & $61.9 \%$ & 8 & $38.1 \%$ & & & \\
\hline Occupation & $\mathbf{N}$ & \multicolumn{2}{|c|}{$\begin{array}{l}\text { Inadequate } \\
\text { n } \%\end{array}$} & \multicolumn{2}{|c|}{\begin{tabular}{|l} 
Moderatly \\
adequate \\
n $\%$
\end{tabular}} & \multicolumn{2}{|c|}{$\begin{array}{l}\text { Adequate } \\
\text { n } \%\end{array}$} & $\chi^{2}$ & Df & p-value \\
\hline $\begin{array}{l}\text { Unemployed/ } \\
\text { Homemaker }\end{array}$ & 188 & 0 & $0.0 \%$ & 175 & $93.1 \%$ & 13 & $6.9 \%$ & 324.586 & 6 & $.001 * *$ \\
\hline $\begin{array}{l}\text { Service/ } \\
\text { employee }\end{array}$ & 22 & 0 & $0.0 \%$ & 22 & $100.0 \%$ & 0 & $0.0 \%$ & & & \\
\hline Agricultural & 91 & 1 & $1.1 \%$ & 45 & $49.5 \%$ & 45 & $49.5 \%$ & & & \\
\hline Own business & 55 & 39 & $70.9 \%$ & 16 & $29.1 \%$ & 0 & $0.0 \%$ & & & \\
\hline Parity & $\mathbf{N}$ & & $\begin{array}{r}\text { lequate } \\
\%\end{array}$ & $\begin{array}{l}\text { Moc } \\
\text { adec } \\
\text { n }\end{array}$ & $\begin{array}{l}\text { atly } \\
\text { ite }\end{array}$ & $\begin{array}{l}\text { Ad } \\
\text { n }\end{array}$ & $\begin{array}{l}\text { uate } \\
\qquad \%\end{array}$ & $\chi^{2}$ & Df & p-value \\
\hline Single & 168 & 23 & $13.7 \%$ & 135 & $80.4 \%$ & 10 & $6.0 \%$ & 25.311 & 2 & $.001 * *$ \\
\hline Two/or more & 188 & 17 & $9.0 \%$ & 123 & $65.4 \%$ & 48 & $25.5 \%$ & & & \\
\hline
\end{tabular}

*Statistically significant at 0.05 level of significance

$* *$ Statistically significant at $<0.01$ level of significance

The table 5 indicates that the place of residence $\left(\chi^{2}=305.761, \mathrm{p}=.001 * *\right)$ and Education $\left(\chi^{2}=\right.$, $34.411 \mathrm{p}=.002 *)$ was highly significant with JSSK awareness and occupation $\left(\chi^{2}=324.586\right.$, 
$\left.\mathrm{p}=.001^{* *}\right),\left(\chi^{2}=25.311 \mathrm{p}=.001^{* *}\right)$, was significant with JSSK awareness which signifies the association between place of residence, education and occupation with JSSK awareness.

\section{Discussion \& Conclusion}

Awareness of Janani Shishu Surakasha Karyakaram:-

The present study showed that out of 356 women, only $18.8 \%$ women heard about the name of the JSSK. Majority (92.7\%) was aware about free vaginal delivery and caesarean section, $84.3 \%$ aware about free drugs and $73.0 \%$ aware about free treatment for sick infants. These findings are slightly higher than the similar study done in Maharashtra that revealed $86.90 \%$ as $73.45 \%$ and $66.2 \%$ respectively (Deshpande et al, 2016).

In the present study, the awareness level regarding the healthcare services was $72.5 \%$, which is almost similar to that of study conducted in Karnataka with $75 \%$ awareness regarding JSSK scheme (Manjula K et al, 2016), whereas another study in Visakhapatnam found higher awareness $(87.8 \%$ ) in this context (Revu S et al, 2018).

\section{Conclusion}

Awareness level of JSSK entitlements in the beneficiaries in our study was (72.5\%) moderately adequate. Maximum awareness was noticed for the provision of free vaginal delivery whereas awareness for provisions like free caesarean section, free drop back facility to home, free provision of blood was very low.

\section{References}

1.Barua, K., Baruah, R., Ojah, J. \& Saikia, A.M. (2016) Factors influencing the utilization of free delivery care under Janani Shishu Suraksha Karyakram in Kamrup district, Assam, India. International Journal of Community Medicine and Public Health, 3 (6), 1665-1671. doi: 10.18203/2394-6040.ijcmph20161647

2. www.nrhmhp.gov.in/sites/default/files/files/Goal\%20no \%203.pdf

3. Chandrakar, A., Panda, P. S., Soni, G. P., \& Dixit, S. (2017). Awareness regarding Janani Shishu Suraksha Karyakram (JSSK) among mothers: a community based cross-sectional study in rural area of Raipur district, Chhattisgarh. International Journal of Research in Medical Sciences, 5(10), 4374-4379.

4. Deshpande, S., Gadappa, S., Pagare, S., Dhaduti, R., \& Andurkar, S. (2017). Awareness regarding Janani Shishu Suraksha Karyakram among pregnant women of Marathwada, Maharashtra, India. Int J Reprod Contracept Obstet Gynecol, 5(6), 1985-91

5. Iyengar SD, Iyengar $\mathrm{K}$, Suhalka V, Agarwal K. Comparison of domiciliary and institutional delivery-care practices in rural Rajasthan, India. J Health Popul Nutr. 2009;27:303-12.

6. Manjula, K., Ravish, K. S., \& Ranganath, T. S. (2017). The awareness and utilization of maternity benefit schemes among women receiving postnatal services in a tertiary care centre. International Journal Of Community Medicine And Public Health, 3(6), 1660-1664.

7. Ministry of Health and Family Welfare. Guidelines for Janani-Shishu Suraksha Karyakram (JSSK). National Rural Health Mission, Maternal Health Division, Government of India, Nirman Bhavan, New Delhi June 2011.

8. Shubha, D. B., Angadi, N., \& Nagarajachari, A. (2016). Infant and young child feeding practices of working and nonworking mothers in urban slums of Davangere city. International Journal of Medical Science and Public Health, 5(3), 420-425.

9. Tyagi, U., Pattabi, K., \& Kaur, P. (2016). Utilization of services under Janani Shishu Suraksha Karyakram for institutional deliveries in the public sector facilities, Sirmaur District, Himachal Pradesh, India. Indian journal of community medicine: official publication of Indian Association of Preventive \& Social Medicine, 41(1), 65

10. Revu S, Kodali VR, Donganti HD. Study of impact of JSSK scheme on institutional deliveries and maternal mortality rate: Visakhapatnam district Andhra Pradesh. Int J Res Med Sci 2018;6:160-6.

11. Sahu, K. S., \& Bharati, B. (2017). Out-of-Pocket health expenditure and sources of financing for delivery, postpartum, and neonatal health in urban slums of Bhubaneswar, Odisha, India. Indian 
DOI : https://dx.doi.org/10.26808/rs.ph.i10v1.02

International Journal of Pharmaceutical Science and Health Care

Issue 10, Vol.1 (Jan. Feb 2020)

Available online on http://www.rspublication.com/ijphc/index.html

ISSN $2249-5738$ journal of public health, 61(2), 67.

12. World Health Organization. Trends in Maternal Mortality: 1990 to 2013. Estimates of WHO,UNICEF, UNFPA. The World Bank and the United Nations Population Division. Geneva, Switzerland:World $\backslash$ Health Organization (WHO); 2014: 1-56.

13. World Health Organization. World Health Statistics 2013. Geneva, Switzerland: World Health Organization; 2013: 134-135. 